\title{
Study of Mobility and Environmental Contamination by Chromium from Tannery Industry in two Streams in the Town of Dobrada in the State of São Paulo, Brazil
}

\author{
Gomes, V. M.; Magdalena, A. G.;* Ramos, D. D.; Santos, A.; Zara, L. F.; \\ Santos, F. A.
}

Rev. Virtual Quim., 2017, 9 (5), 1840-1852. Data de publicação na Web: 24 de agosto de 2017

http://rvq.sbq.org.br

\begin{abstract}
Estudo da Mobilidade e da Contaminação Ambiental pelo Cromo da Indústria de Curtumes em Dois Córregos na Cidade de Dobrada no Estado de São Paulo, Brasil
\end{abstract}

Resumo: Cromo é usado no processo de curtimento de couro. Em consequência, o armazenamento impróprio do couro pode impactar o ambiente. Este estudo avaliou a mobilidade do cromo resultante da disposição de aparas de couro e sua influência no solo, na água (águas superficiais e subterrâneas) e sedimentos em dois riachos na cidade de Dobrada, no estado de São Paulo. Os riachos são conhecidos localmente como o Córrego de Paixão e o Córrego de Dobrada. Os resultados obtidos indicam que o solo, os sedimentos e a água na área estudada foram contaminados pelo cromo dos resíduos de curtumes. Além disso, os resultados mostraram que a decomposição deste resíduo modifica o $\mathrm{pH}$ e a condutividade do solo e da água e alteram as características físico-químicas da região. Os resultados também revelaram que o cromo está disponível no ambiente biótico e que sua concentração está acima do limite legal para o país.

Palavras-chave: Contaminação por Cromo; impacto ambiental pela indústria de couro.

\begin{abstract}
Chromium is used in the leather tanning process. As a consequence, improper leather storage can impact the environment. This study has evaluated the mobility of chromium resulting from the disposal of leather trimmings and its influence on soil, water (surface water and underground water), and sediments in two streams in the town of Dobrada, in the state of São Paulo, Brazil. The streams are known locally as the Paixão Stream and the Dobrada Stream. The results obtained indicate that the soil, sediments, and water in the area studied were contaminated by chromium from tannery waste. Besides that the results showed that the decomposition of this waste modifies the $\mathrm{pH}$ and conductivity of the soil and water and changes the physical chemistry characteristics of the region. The results also revealed that chromium is available in the biotic environment and that its concentration is above the legal limit for the country.
\end{abstract}

Keywords: Chromium contamination; environmental impact of the leather industry.

\footnotetext{
* São Paulo State University, School of Science, Address: Av. Engenheiro Luiz Edmundo Coube, 1401, CEP 17033-360, Bauru-SP, Brazil.

Maroldogm@fc.unesp.br DOI: $\underline{10.21577 / 1984-6835.20170108}$
} 


\title{
Study of Mobility and Environmental Contamination by Chromium from Tannery Industry in two Streams in the Town of Dobrada in the State of São Paulo, Brazil
}

\author{
Vinicius M. Gomes, ${ }^{a}$ Aroldo G. Magdalena, ${ }^{b}, *$ Dayana D. Ramos, ${ }^{c}$ Ademir \\ dos Santos, ${ }^{a}$ Luiz F. Zara, ${ }^{d}$ Felipe A. Santos ${ }^{c}$ \\ ${ }^{a}$ São Paulo State University, Institute of Chemistry, Addrees: Av. Prof. Francisco Degni, 55 - \\ Quitandinha, CEP 14.800-900, Araraquara-SP, Brazil. \\ ${ }^{\text {b }}$ São Paulo State University, School of Science, Address: Av. Engenheiro Luiz Edmundo Coube, \\ 1401, CEP 17033-360, Bauru-SP, Brazil. \\ ' São Paulo State University, School of Science and Engineering, Address: Rua Domingos da \\ Costa Lopes, 780, CEP 17602-496, Tupã-SP, Brasil. \\ d University of Brasilia, Address: Área Universitária 01, Vila Nossa Senhora de Fátima, CEP \\ 73300-000, Planaltina-GO, Brazil. \\ *aroldogm@fc.unesp.br
}

1. Introduction

2. Experimental Procedure

2.1. Samples: Soil, Water, Sediments

\section{Results and Discussion}

4. Conclusion

\section{Introduction}

Environmental questions have been discussed by science in recent years due to the need to preserve the hydrosphere, atmosphere, and lithosphere, and to consider the consequences for organisms. Studies on contamination caused by metals as well as environmental remediation of impacted areas as a result of human activity have recently become relevant. An example of this type of contamination occurred in the town of Dobrada, in the state of São Paulo, Brazil, where tannery waste was improperly stored. Dobrada is a municipality in the state of São Paulo. Located $350 \mathrm{~km}$ from the capital of São Paulo with the latitude of $21^{\circ} 31^{\prime} 00^{\prime \prime}$ south and the longitude $48^{\circ} 23^{\prime} 38^{\prime \prime}$ west. It was kept in direct contact with the soil for approximately nine years in a location close to an urban area and on top of a spring that was an important source of freshwater for the city.

One of the most significant problems of urbanization and industrialization is 
accumulated waste, which is frequently disposed of inadequately and which can cause serious environmental problems. Contamination by metals has been widely studied, including the study of chromium contamination. ${ }^{1-10}$ Chromium can be used in the production of stainless steel, pigments, ceramics, rubber, magnetic bands, and leather. ${ }^{4}$ In the specific case of leather production, chromium is used to tan leather. The tanning process consists of chemical reactions between chemical elements (such as chromium) and proteins. It leads to the transformation of the hide's collagen into leather. Adding chromium to the process of making leather provides higher hydrothermal stability, flexibility, and resistance. ${ }^{5}$

Chromium can present different oxidation states, the most stable of which are $\mathrm{Cr}$ (III) and $\mathrm{Cr}$ (IV). $\mathrm{Cr}$ (II) is essential to human health and is responsible for several regulatory and cellular processes, ${ }^{11}$ while $\mathrm{Cr}$ (IV) is toxic to the human body because of its elevated oxidation potential and its ability to pass through biological barriers. It is considered carcinogenic. ${ }^{12}$ Redox reactions involving chromium can occur in the natural environment and contaminate soils, streams, and the water table.

This study evaluates the mobility of chromium from the disposal of tannery waste and its influence on the soil, sediments and streams in the town of Dobrada, in the state of São Paulo, Brazil.

\section{Experimental Procedure}

\subsection{Samples: Soil, Water, Sediments}

In order to evaluate the distribution and bioavailability of chromium, soil samples were collected from different depths in the area where solid waste had been discarded. The sediment and surface water samples were collected from the streams known locally as the Paixão Stream and the Dobrada Stream, which are springs below the location where the tannery waste had been deposited. The samples were collected at points upstream, downstream, and in the area influenced by the tannery waste deposits, as illustrated by Fig 1 . The underground water samples were collected from springs downstream, upstream, and in the area influenced by the waste.

In order to control for the effect of seasonality, the samples were collected in February (during the summer) during a long period of rains and in August (winter) during a period of drought.

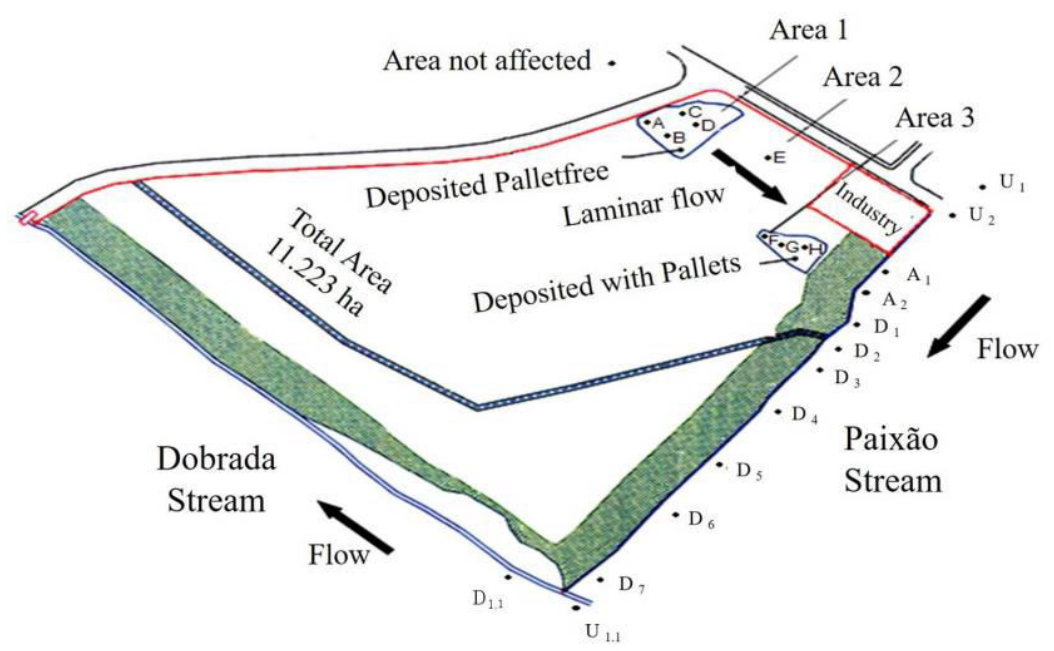

Figure 1. Illustrative figure the map of the study area showing the sampling points. ( $A$ to $\mathrm{H}$ : soil sampling points, $U$ : upstream points, $A$ : area of influence and $D$ : downstream subterranean surface water and sediment sampling points.) 
The soil samples were collected along the banks of the streams in triplicate using a backhoe at eight different points $(A, B, C, D$, $E, F, G$, and $H$ ) with approximately 10 meters between them and at depths of 0-10 cm, 10$20 \mathrm{~cm}, 20-40 \mathrm{~cm}, 40-60 \mathrm{~cm}, 60-100 \mathrm{~cm}, 100-$ $150 \mathrm{~cm}, 150-200 \mathrm{~cm}$, and $200-250 \mathrm{~cm}$. The sampling points were separated into different areas due to the slope of the terrain and the distribution of the tannery waste in the sampling area.

The collection and preservation of soil samples were performed according to CETESB recommendations. ${ }^{13}$

Sediment samples were collected from the Paixão Stream at points upstream, downstream, and in the area of influence of tannery waste. They were also collected from the Dobrada Stream at points upstream and downstream. ${ }^{14}$

The collection and preservation of the sediment samples were performed according to CETESB guidelines, described below. The samples of superficial sediment were carried out using an Ekman-Birge trap modified by the authors, stored in a plastic bag at $4{ }^{\circ} \mathrm{C} .{ }^{15}$

Surface water samples were collected from the Paixão Stream at points upstream in the area of influence and downstream from the tannery waste deposits. Samples were collected upstream and downstream in the Dobrada Stream, a water body that receives water from the other stream. Underground water samples were collected from springs that empty into both the Paixão Stream and the Dobrada Stream at the same points.

The collection and preservation of surface and groundwater samples were performed according to CETESB recommendations, as described below. Samples were collected directly in polyethylene bottles. These vials were previously decontaminated in the laboratory with $10 \%$ nitric acid solution, and at the sampling site were washed 3 times. The surface water samples were collected directly in the river stream, with the mouth of the flask always turned towards the water flow and the groundwater samples were collected directly from the mine. After collection the samples were stored at $4{ }^{\circ} \mathrm{C} .{ }^{15}$

The physical and chemical parameters, $\mathrm{pH}$, and conductivity were determined using a properly calibrated YSI 600QS multiparameter sonde.

After the samples were treated, acid mineralization was applied to the soil and sediment samples in which approximately $2.00 \mathrm{~g}$ of the samples were transferred to the digestion tube and $10.0 \mathrm{~mL}$ of hydrogen peroxide was added and allowed to stand for 12 h. Subsequently, it was added concentrated nitric acid solution and heating the mixture at a temperature of approximately $120{ }^{\circ} \mathrm{C}$, until complete digestion of the organic matter (clear extract and insoluble material). The extracts were transferred to $100.00 \mathrm{~mL}$ volumetric flask. For water samples, $100.00 \mathrm{ml}$ of sample was transferred to digestion tube packed in a digester block and then $15.00 \mathrm{ml}$ of concentrated nitric acid solution was added and, under heating of $150{ }^{\circ} \mathrm{C}$, the mixture was evaporated to $50 \mathrm{ml}$. After addition of $1.00 \mathrm{~mL}$ of $30 \%(\mathrm{v} / \mathrm{v})$ hydrogen peroxide solution the sample was allowed to reflux until the end of digestion using the rod funnel to transfer the extract to $100.00 \mathrm{~mL}$ volumetric flask. ${ }^{4}$

The determinations were made by atomic emission spectrometry with induced argon plasma (ICP OES), Thermo Jarrel Ash, model IRIS/AP, using mixed standard solutions for the calibration curve and the following operating conditions: simultaneous detection (CID "Change-injection device"); Axial reading; Concentric nebulizer, 32 psi; Pressure in the nebulizer chamber, $30 \mathrm{psi}$; Nebulization gas and argon refrigeration; Sample aspiration, $1.9 \mathrm{~mL} \mathrm{~min}^{-1}$; Auxiliary gas flow, $0.50 \mathrm{~L} \mathrm{~min}^{-1}$; Radio frequency, $1350 \mathrm{~W}$; Integration time, $20 \mathrm{~s}$ and with emission line at the wavelength of $267.71 \mathrm{~nm} .^{16}$

For the determination of the accuracy method were made in triplicates and for the calculation of detection and quantification limit were used adopted criteria by IUPAC. In 
the study the chromium accuracy were used the standard additions method and the recovery was $95 \%$, the detection and quantification limit in the water method were 0.003 and $0.01 \mathrm{mg} \mathrm{L}^{-1}$, while for the sediment was 0.13 and $0.5 \mathrm{mg} \mathrm{kg}^{-1}$.

To quantify the amount of bioavailable chromium, $2.5 \mathrm{~g}$ of a dry sample was transfered to a $100 \mathrm{~mL}$ vial, and $50 \mathrm{~mL}$ of a $0.10 \mathrm{~mol} \mathrm{~L}^{-1}$ chloridric acid solution was added. The solution was shaken at $200 \mathrm{rpm}$ for 2 hours in a shaker. The suspension was then filtered on Whatman 42 paper, transferred to a glass vial, and stored at $4 \stackrel{\circ}{ } \mathrm{C}$. The quantification was performed in the same conditions describe by ICP-OES. ${ }^{14,16,17}$

\section{Results and Discussion}

To study the physical chemical characteristics of the soil, $\mathrm{pH}$ and conductivity assays were performed on samples from different depths. The $\mathrm{pH}$ and conductivity results are presented in Table 1. The $\mathrm{pH}$ values at most of the sampling points were above the values found in areas not affected by the local leather factory (the cores), a difference which revealed a basic trait of the soil. The conductivity assays were also higher than the values in the control samples from the cores. This data sample supports the theory that the collection points from $A$ to $H$ are more basic due to the transformation of organic nitrogen from the tannery waste into ammonium nitrate. ${ }^{4,11,16}$ Higher $\mathrm{pH}$ at lower depths is explained by the fact that ammonia-based composts are relatively volatile. ${ }^{4,9,10,16}$ These results indicate that tannery waste are decomposing in the soil, leading to an increase in soil conductivity and promoting changes in the physical and chemical characteristics of the soil.
In order to evaluate chromium mobility, total and bioavailable chromium concentration assays were performed on soil samples from Areas 1, 2, and 3, which were then compared to the area that had not been affected by the tanning factory. Fig 2 -a shows the range in the total and bioavailable chromium concentrations at different sampling points (from point $A$ until point $H$ ) and at depths between 0 and $10 \mathrm{~cm}$. In this graph, it is possible to observe that chromium concentrations were higher than control concentrations at every sampling point. In the graphs of figure 2 it was observed that the total chromium concentration was above the legal limit of chromium concentration permitted by CONAMA Resolution No. 420 (400 mg Kg${ }^{-1}$ ) at points $A, B, C, D$ and $F$, in addition, the bioavailable chromium concentration was above only at points $A$ and $B$. At point $C$, the highest value of the total chromium concentration was about 7.5 times greater than the legal limit of chromium concentration permitted by CONAMA Resolution No. 420 (400 mg kg-1), while at points $A$ and $B$ the bioavailable chromium concentration was above about 1.5 times. These results are an indication that the region is affected by this metal.

These results are in line with $\mathrm{pH}$ and conductivity values (Table 1). According to Brazil's National Environment Council (CONAMA), ${ }^{18}$ the legal limit of chromium concentration in the soil is $400 \mathrm{mg} \mathrm{kg}^{-1}$. Because the chromium concentrations found herein are above the legal limit, there is evidence of chromium contamination of the soil caused by the local tanning factory. Total and bioavailable chromium concentration assays were performed on samples from different depths. Fig 2-b shows the graph for Point C, located in Area 1. This graph illustrates that the total concentration decreases as depth decreases, while bioavailable concentration is almost constant among the different depths. 
Table 1. $\mathrm{pH}$ and conductivity values as a function of depth in the areas studied

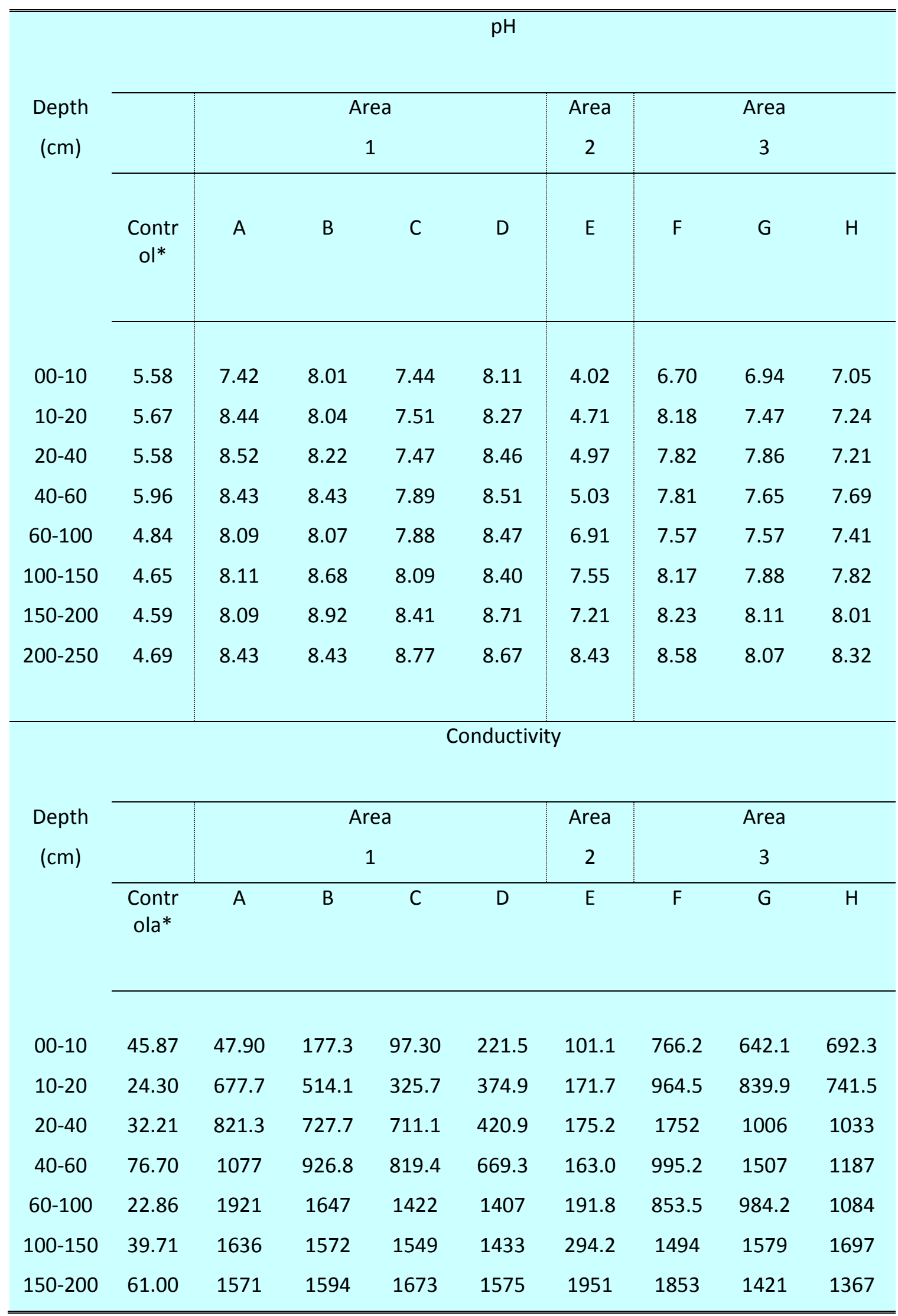

*Area not affected by the local tanning factory 

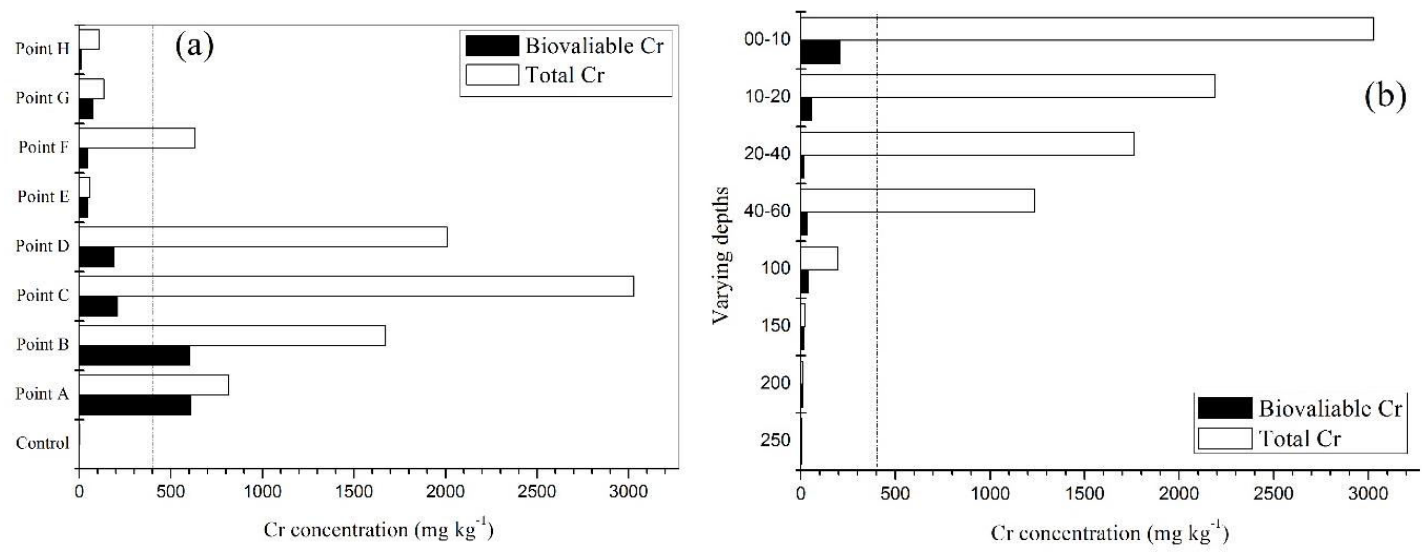

Figure 2. (a) Curve for the concentration of total and bioavailable chromium at depths of 0 to $10 \mathrm{~cm}$ in all of the areas studied. (b) Range in concentrations of total and bioavailable chromium at varying depths of Point $\mathrm{C}$, in the Area 1. Legend: The dotted line indicates the legal limit of chromium concentration permitted by CONAMA Resolution No. $420\left(400 \mathrm{mg} \mathrm{Kg}^{-1}\right)^{18}$

The results show that the layer of the soil with the highest chromium concentration was the surface soil, but high concentrations of chromium were occasionally observed at deeper depths, as shown in the graph of Fig. 2-b that until the depth of $40-60 \mathrm{~cm}$ the total chromium concentration was 3.1 times higher than the legal limit of chromium concentration permitted by CONAMA Resolution No. $420\left(400 \mathrm{mg} \mathrm{Kg}^{-1}\right)$, after this depth the value becomes lower than chromium concentration permitted by CONAMA Resolution No. $420(400 \mathrm{mg} \mathrm{Kg}$ $\left.{ }^{1}\right){ }^{18}$ This result indicates that the tannery waste products are decomposing. These results are consistent with those obtained in the $\mathrm{pH}$ analysis. The results also suggest that bioavailable chromium may be associated with soil organic matter and could contaminate the water table through leaching.

Because the results of the analysis show that the soil has been contaminated by chromium from the local tanning factory, experiments on surface water, groundwater, and sediments were performed in order to determine whether the element was undergoing diffusion into the water due to leaching of the soil.
In order to analyze the surface water and groundwater, samples of underground water were also collected from springs and surface water from the Paixão Stream and the Dobrada Stream in two different periods: after a twenty-day drought and immediately after rainfall. Conductivity and $\mathrm{pH}$ data of the surface water and groundwater samples is represented in Tables 2 and 3, respectively, and is organized by the map of the region.

The $\mathrm{pH}$ values obtained for the surface water and the groundwater were almost constant. However, conductivity increased in value compared to samples collected from a location near the area where tannery waste was deposited (upstream). This increase in conductivity is likely caused by the formation of ammonium hydroxide and its diffusion to the river, ${ }^{4,11,16}$ a finding which is consistent with the soil $\mathrm{pH}$ and conductivity data shown in Tables 1. This increase may also be due to the salts dissolved in the water, particularly chromium. ${ }^{6}$ Tables 2 and 3 showed that the $\mathrm{pH}$ of the water during the rainy season is higher than that of the dry season. This difference is likely due to the hypothesis of chromium being leached from the soil and the water. 
Table 2. Conductivity and $\mathrm{pH}$ values of surface water samples of from the the Paixão Stream and the Dobrada Stream.

\begin{tabular}{|c|c|c|c|c|c|}
\hline \multirow[b]{2}{*}{ Stream } & \multirow[b]{2}{*}{ Point } & \multicolumn{2}{|c|}{ Drought } & \multicolumn{2}{|c|}{ Rain } \\
\hline & & $\mathrm{pH}$ & $\begin{array}{l}\text { Conductivity } \\
\qquad\left(\mu \mathrm{S} \mathrm{cm}{ }^{-1}\right)\end{array}$ & $\mathrm{pH}$ & $\begin{array}{l}\text { Conductivity } \\
\left(\mu \mathrm{S} \mathrm{cm}^{-1}\right)\end{array}$ \\
\hline \multirow{11}{*}{$\begin{array}{l}\text { Paixão } \\
\text { Stream }\end{array}$} & $U_{1}$ & 6.98 & 156.8 & 6.71 & 139.1 \\
\hline & $\mathrm{U}_{2}$ & 6.99 & 155.2 & 6.65 & 198.7 \\
\hline & $A_{1}$ & 7.02 & 157.2 & 6.81 & 285.3 \\
\hline & $\mathrm{A}_{2}$ & 7.02 & 156.5 & 6.82 & 291.7 \\
\hline & $\mathrm{D}_{1}$ & 6.96 & 168.4 & 6.91 & 257.3 \\
\hline & $D_{2}$ & 6.97 & 171.8 & 6.99 & 274.6 \\
\hline & $\mathrm{D}_{3}$ & 6.99 & 158.6 & 7.00 & 301.9 \\
\hline & $\mathrm{D}_{4}$ & 6.49 & 231.5 & 7.04 & 287.9 \\
\hline & $D_{5}$ & 6.42 & 245.3 & 6.98 & 291.1 \\
\hline & $D_{6}$ & 6.52 & 242.2 & 6.72 & 274.5 \\
\hline & $D_{7}$ & 6.54 & 244.3 & 6.82 & 321.7 \\
\hline \multirow{2}{*}{$\begin{array}{l}\text { Dobrada } \\
\text { Stream }\end{array}$} & $\mathrm{U}_{1.1}$ & 6.15 & 128.1 & 6.52 & 177.3 \\
\hline & $\mathrm{D}_{1.1}$ & 6.75 & 128.7 & 6.78 & 198.2 \\
\hline
\end{tabular}

Legend: U: Upstream; A: Area of influence; D: Downstream.

Tables 2 and 3 showed the conductivity values for the samples, ranging from 139.1 and $321.7 \mu \mathrm{S} \mathrm{cm}^{-1}$ for the surface water and 198.7 and $1976 \mu \mathrm{S} \mathrm{cm} \mathrm{cm}^{-1}$ for groundwater samples. The electrical conductivity is directly related to ions dissolved in an aqueous medium, ${ }^{6}$ so that the greater the amount of ions will be greater the conductivity of the water analyzed. This is an important parameter for evaluating water quality, since in general, sites with conductivity levels greater than $100 \mu \mathrm{S} \mathrm{cm}^{-1}$ can be classified as impacted regions. ${ }^{6,19,20}$ In this study, all samples were above $100 \mu \mathrm{S} \mathrm{cm}^{-1}$ indicating that the aquatic ecosystem is impacted.
The cause for this increase in $\mathrm{pH}$ may be the transportation of ammonium hydroxide formed in the soil by the decomposition of the tannery waste into the water table along with soluble solids, which may also increase conductivity. ${ }^{4,11,16}$ This data is consistent with the soil findings and reflects the influence of the rain, which increases water $\mathrm{pH}$. Rainwater aids in the transportation of ammonium hydroxide from the soil to the water. Groundwater conductivity was found to be higher than surface water conductivity. This difference points to a higher concentration of conducting solids in that region, which is due to the influence of the sedimentation of these particles. 
Table 3. Conductivity and $\mathrm{pH}$ values from the groundwater samples collected from the Paixão Stream and the Dobrada Stream

\begin{tabular}{cccccc}
\hline Stream & Point & \multicolumn{2}{c}{$\begin{array}{c}\text { Drought } \\
\text { Conductivity } \\
\left(\mu \mathrm{cm}^{-1}\right)\end{array}$} & $\mathrm{pH}$ & $\begin{array}{c}\text { Rain } \\
\text { Conductivity } \\
\left(\mu \mathrm{S} \mathrm{cm}^{-1}\right)\end{array}$ \\
\hline & $\mathrm{U}_{1}$ & 5.82 & 191.1 & 6.42 & 198.7 \\
& $\mathrm{U}_{2}$ & 5.58 & 308.5 & 6.11 & 206.1 \\
& $\mathrm{~A}_{1}$ & 5.82 & 307.6 & 5.99 & 231.0 \\
& $\mathrm{~A}_{2}$ & 5.66 & 1723 & 6.09 & 567.9 \\
Paixão & $\mathrm{D}_{1}$ & 5.80 & 1305 & 6.45 & 912.6 \\
& $\mathrm{D}_{2}$ & 5.87 & 171.8 & 6.71 & 1324 \\
& $\mathrm{D}_{3}$ & 5.24 & 802.6 & 6.73 & 1976 \\
& $\mathrm{D}_{4}$ & 5.29 & 782.7 & 6.77 & 1871 \\
& $\mathrm{D}_{5}$ & 5.32 & 161.0 & 6.54 & 1270 \\
& $\mathrm{D}_{6}$ & 5.58 & 157.2 & 6.60 & 1130 \\
& $\mathrm{D}_{7}$ & 5.61 & 155.8 & 6.42 & 764.9 \\
\hline Dobrada & $\mathrm{U}_{1.1}$ & 6.27 & 80.2 & 6.59 & 211.7 \\
& $\mathrm{D}_{1.1}$ & 6.42 & 127 & 6.77 & 252.2 \\
\hline
\end{tabular}

Legend: U: Upstream, A: Area of influence, D: Downstream

Fig 3 shows the total chromium concentrations obtained from the surface water samples collected from the Paixão Stream and the Dobrada Stream. This graph reflects the higher total chromium concentrations downstream from the affected area; all of the results were found to be above the legal limits established by CONAMA Resolution No. 420 for the underground water and the CONAMA Resolution No. 357 for the surface water $\left(0.05 \mathrm{mg} \mathrm{L}^{-1}\right)^{18,21}$ This result indicates that chromium contamination of the region's biota occurred and was caused by the local leather factory.
The graphs in Fig 3 show that the chromium concentrations in the water table (Figs. 3-a and 3-c) were higher than those found in the stream (Figs 3-b and 3-d). This data confirms that chromium is present in its crystalline phase and reaches the water table of these streams due to the contamination of the soil by the local leather factory. This finding is also supported by the analysis of underground water after rainy periods, the results of which are shown in Fig 4 . This data reflects contamination of the water in the streams in the sampling areas. 

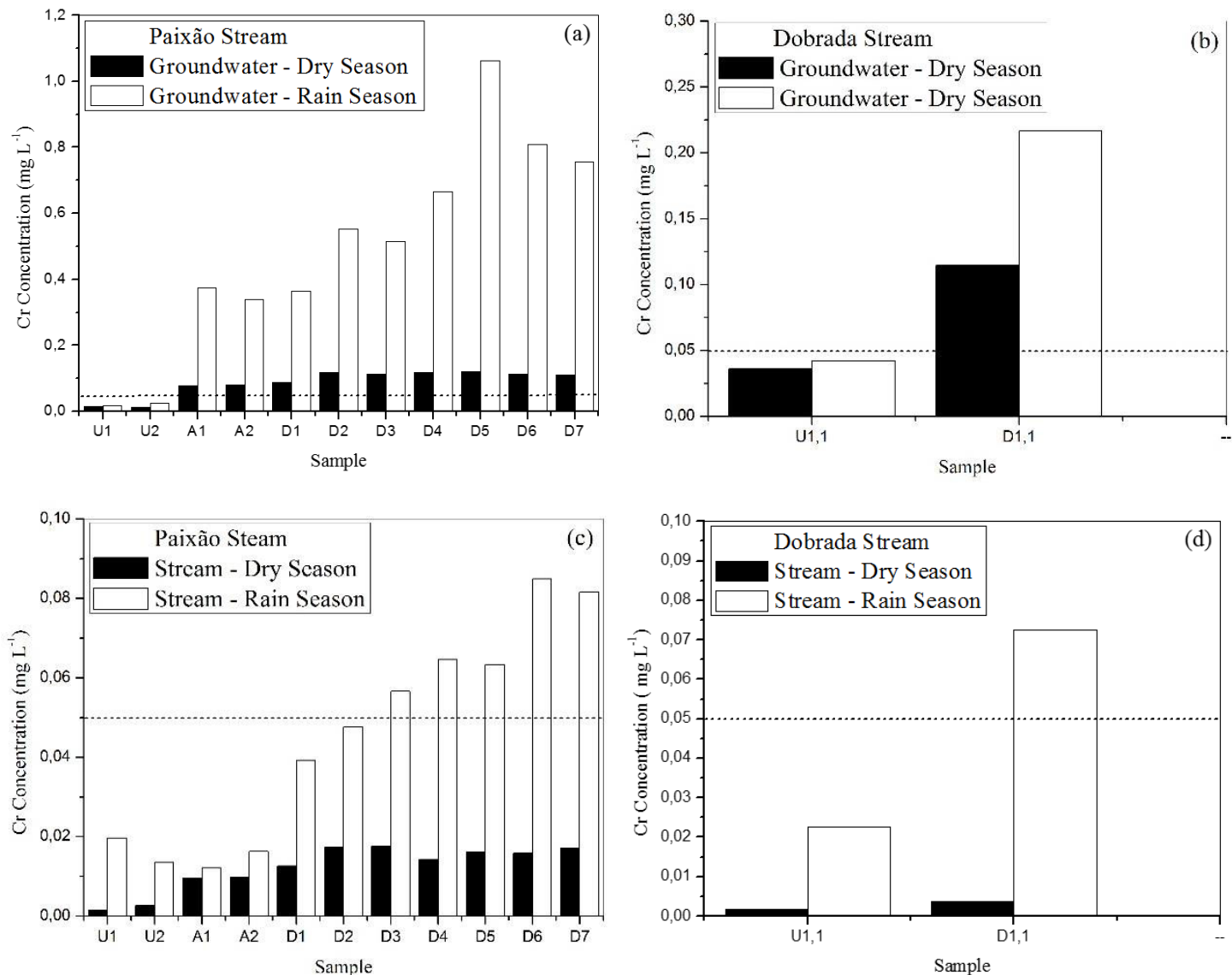

Figure 3. Curve of the concentration of total chromium in the surface water collected from the streams at different sampling points. Differences between the dry season (August 2009) and the rainy season (February 2009) were considered. Legend: The dotted line indicates the legal limit of chromium concentration established by CONAMA Resolution No. 420 and 357, which is $0.05 \mathrm{mg} \mathrm{L}^{-118,21}$

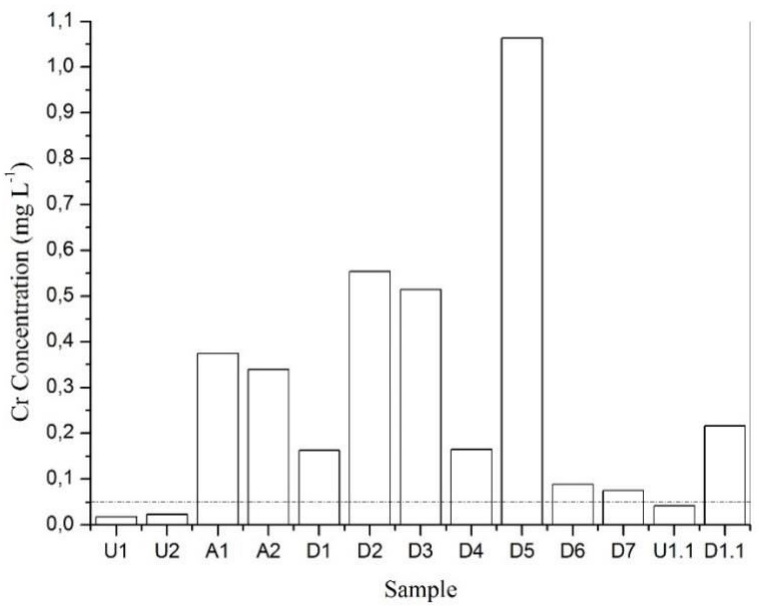

Figure 4. Curve of the total chromium concentrations in underground water from the streams. Samples collected from different sampling points after the rainy period. Legend: The dotted line indicates the legal limit of chromium concentrations established by CONAMA Resolution No. 420, which is $0.05 \mathrm{mg} \mathrm{L}^{-118}$ 
As illustrated in Figs $5 a$ and $5 b$, the results of the surface sediment analysis also indicate high concentrations downstream, which is evidence of the leaching of the metal deposited. The approaches described in the literature and used to evaluate the quality and handling of contaminated sediments relies on sediment quality reference values. In the case of chromium, the threshold effect level (TEL) and probable effects level (PEL) are $37.3 \mathrm{mg} \mathrm{kg}^{-1}$ and $90.0 \mathrm{mg} \mathrm{kg}^{-1} .{ }^{14,22}$

The chromium concentrations in the Sediment samples were collected from the Paixão Stream at points downstream are higher than the upstream (Fig. 5a), they are will below the TEL. In the dry interval the chromium concentrations reached a maximum value of $20 \mathrm{mg} \mathrm{kg}^{-1}$, this value is double that verified for Dobrada Stream (12 $\left.\mathrm{mg} \mathrm{kg}^{-1}\right)$. However, in the rainy period, the chromium concentration in the Paixão Stream reached $32 \mathrm{mg} \mathrm{kg}^{-1}$, approximately half the concentration of the Dobrada Stream which was $57 \mathrm{mg} \mathrm{kg}^{-1}$. This is because the sediments are transported by floods. In the rainy season, the flow of the Paixão Stream increases, and consequently, transports the sediment to the Dobrada Stream, thus, in this period the concentration of chromium in this correction is higher, with values above the TEL.
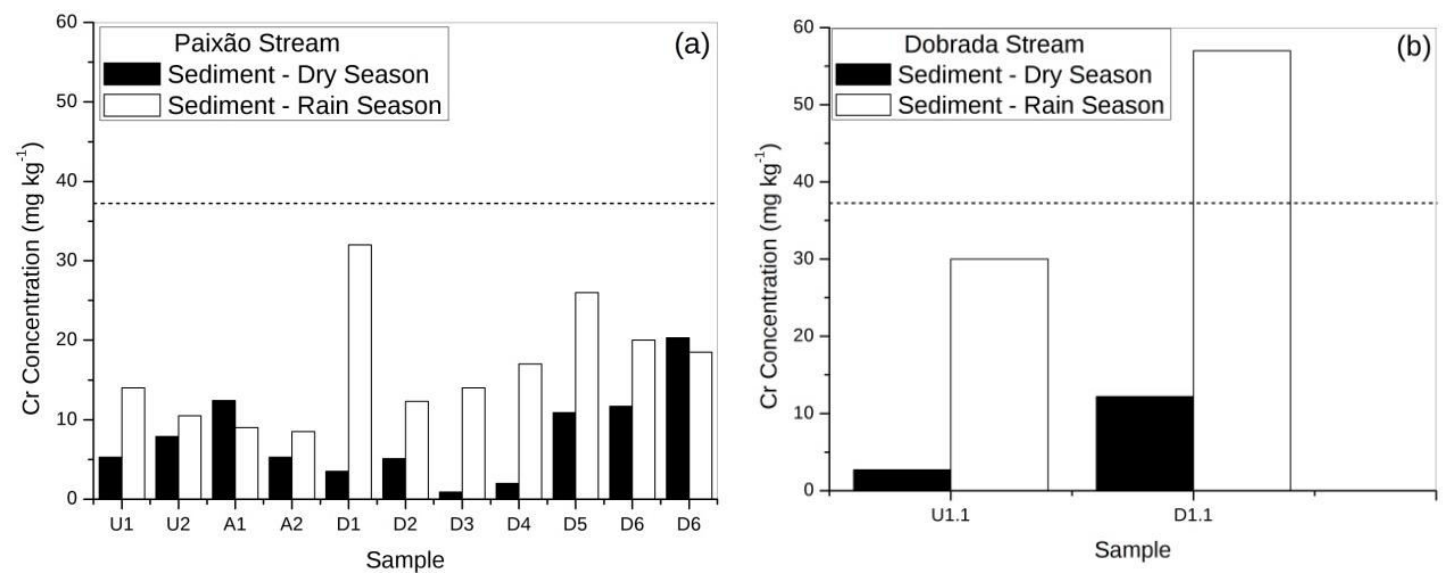

Figure 5. Curve of the total chromium concentrations found in the sediments from the streams at different sampling points immediately after the rainy period. Legend: The dotted line indicates the TEL of chromium concentrations $\left(37.3 \mathrm{mg} \mathrm{kg}^{-1}\right)$ established by CONAMA Resolution No. $454^{22}$

With the results obtained, it is possible to verify that the chromium present in the soil is, indeed, exhibiting mobility and being carried to other compartments.

\section{Conclusion}

The results obtained in this study show that the soil, sediments and water in the areas studied herein have been contaminated by chromium from tannery waste. The results also show that the decomposition of this waste modifies the $\mathrm{pH}$ and conductivity of the soil and water and changes the physical and chemical characteristics of the region. These changes may damage the affected environment.

Despite the decrease in total chromium concentrations at lower depths, a constant concentration of bioavailable chromium was found. This concentration indicates that even low concentrations of chromium are sufficient to make it bioavailable to animals and plants, and that chromium therefore affects the biotic and abiotic environment of this region. 


\section{References}

${ }^{1}$ Moreira, J. C. Threats by heavy metals: human and environmental contamination in Brazil. The Science of the total environmental 1996, 188, 61. [CrossRef] [PubMed]

${ }^{2}$ Tchounwou, P. B.; Yedjou, C. G.; Patlolla, A. K.; Sutton, D. J. Heavy Metal Toxicity and the Environment. Molecular, Clinical and Environmental Toxicology 2012, 101, 133. [CrossRef]

${ }^{3}$ Wolińska, A.; Stępniewska, Z.; Wlosek, R. The influence of old leather tannery district on chromium contamination of soils, water and plants. Natural Science 2013, 5, 253. [CrossRef]

${ }^{4}$ Santos, A.; Oliveira, L. C.; Botero, W. G.; Mendonça, A. G. R.; Santos, F. A.; Rocha, J. C.; Ribeiro, M. L.; Oliveira, A. S. Distribuição e biodisponibilidade de crômio em solos contaminados por resíduos de couro. Química Nova 2009, 32, 1693. [CrossRef]

${ }^{5}$ Muller, T.; Granada, C. E.; Sperotto, R. A. Qualidade da água de três locais com potenciais fontes de contaminação no Rio Taquari, RS. Revista Ambiente \& Água 2016, 11, 75. [CrossRef]

${ }^{6}$ Soares, R.; Machado, W. T. V.; Campos, D. V. B.; Monteiro, M. I. C.; Freire, A. S.; Santelli, R. E. Avaliação da aplicabilidade de índices de poluição aquática: Estudo de caso no Rio Paraibuna (Juiz de fora, MG, Brasil). Revista Virtual de Química 2016, 8, 2105.[CrossRef]

${ }^{7}$ Soares, R.; Carneiroa, M. C.; Monteiro, M. I. C.; Henrique JR., S. S.; Pontes, F. V. M.; Silva, L. I. D.; Alcover Neto, A.; Santelli, R. E. Simultaneous speciation of chromium by spectrophotometry and multicomponent analysis. Chemical Speciation \& Bioavailability 2009, 21, 152. [CrossRef]

${ }^{8}$ Rodrigues, M. L. K.; Formoso, M. L. L. Geochemical distribution of selected heavy metals in stream sediments affected by tannery activities. Water, Air and Soil Pollution 2006, 169, 167. [CrossRef]

${ }^{9}$ Jordão, C. P.; Pereira, J. L.; Jham, G. N. Chromium contamination in sediment, vegetation and fish caused by tanneries in the State of Minas Gerais, Brazil. The Science of the Total Environment 1997, 207, 1. [CrosRef]

${ }^{10}$ Jordão, C. P.; Silva, A. C.; Pereira, J. L.; BRUNE, W. Contaminação por crômio de águas de rios provenientes de curtumes em Minas Gerais. Química Nova 1999, 22, 47. [CrossRef]

${ }^{11}$ Oliveira, H. Chromium as an Environmental Pollutant: Insights on Induced Plant Toxicity. Journal of Botany 2012, 2012, 1. [CrossRef]

${ }^{12}$ Proctor, D. M.; Finley, B. L.; Harris, M. A.; Paustenbach, D. J.; Rabbe, D.; Chromium in soil: perspectives in chemistry, heath and environmental regulation, Lewis: New York, 1997.

${ }^{13}$ Brasil. Companhia de Tecnologia de Saneamento Ambiental - CETESB. Amostragem de solo. São Paulo, 44p, 1999.

${ }^{14}$ Mozeto, A. A.; Umbuzeiro, G. A.; Jardim, W. F. Métodos de coleta, análises físicoquímicas e ensaios biológicos e ecotoxicológicos de sedimentos de água doce. São Carlos, 2006.

${ }^{15}$ Brasil. Companhia de Tecnologia de Saneamento Ambiental - CETESB. Guia nacional de coleta e preservação de amostras: água, sedimento, comunidades aquáticas e efluentes líquidos. São Paulo, 327p, 2011.

${ }^{16}$ Santos, Tese de Doutorado, Universidade de São Paulo, 2003. [Link]

${ }^{17}$ Silvério, P. F.; Dissertação de Mestrado, Universidade de São Paulo, 1999. [link]

${ }^{18}$ CONAMA - Conselho Nacional do Meio Ambiente. Resolução $n^{\circ} 420$. Dispõe sobre critérios e valores orientadores de qualidade do solo quanto a presença de substâncias químicas e estabelece diretrizes para o gerenciamento ambiental de áreas contaminadas por essas substâncias em decorrência de atividades antrópicas, 2009. [Link]

${ }^{19}$ Alves, E. C.; Silva, C. F.; Cossich, E. S.; Tavares, C. R. G.; Filho, E. E. S.; Carniel, A. Avaliação da qualidade da água da bacia do rio Pirapó - Maringá, Estado do Paraná, por meio de parâmetros físico, químicos e microbiológicos. Acta Scientiarum Technology 2008, 30, 39. [CrossRef] 
${ }^{20}$ Oliveira, B. S. S.; Cunha, A. C. Correlação entre qualidade da água e variabilidade da precipitação no sul do Estado do Amapá. Revista Ambiente \& Água 2014, 9, 261. [CrossRef]

${ }^{21}$ CONAMA - Conselho Nacional do Meio Ambiente, Resolução $n^{\circ} 357$. Dispõe sobre a classificação dos corpos de água e diretrizes ambientais para o seu enquadramento, bem como estabelece as condições e padrões de lançamento de efluentes, e dá outras providências, 2005. [link]

${ }^{22}$ CONAMA - Conselho Nacional do Meio Ambiente. Resolução $n^{\circ} 454$. Estabelece as diretrizes gerais e os procedimentos referenciais para o gerenciamento do material a ser dragado em águas sob jurisdição nacional, 2012. [Link] 